\title{
TERAJU
}

Teraju: Jurnal Syariah dan Hukum

Volume 01 Nomor 02, September 2019

DOI: $10.35961 /$ teraju.v1i02.47

\section{Tradisi Pemberian Sumbangan Dalam Hajatan Pernikahan Persfektif Fiqhul Islam}

\author{
Astizal \\ STAIN Sultan Abdurrabman Kepulauan Riau \\ asrizal@stainkepri.ac.id
}

Pipin Armita

Insitut Sains Al-Qur'an Syekh Ibrabim Rokan Hulu

pipinarmita@gmail.com

Afriadi Putra

UIN Sultan Syarif Kasim Riau

afriadi.putra@uin-suska.ac.id

Bashori

UIN Imam Bonjol Padang

bashori@uinib.ac.id

\begin{abstract}
Abstrak
Dalam tulisan ini akan sedikit membahas mengenai sumbangan yang diberikan ketika hajatan pernikahan. Sehingga dapat digambarkan bahwa seluruh lapisan masyarakat menganggap penting diterapkan tradisi sumbangan dalam hajatan pernikahan. Permasalahan ini akan dikaji dengan menggunakan metode penelitian dengan pendekatan kualitatif, yaitu suatu proses penelitian dan pemahaman yang berdasarkan pada metodologi yang menyelidiki suatu fenomena sosial dan masalah manusia. Mengenai tradisi sumbangan dalam hajatan pernikahan ini sudah menjadi tradisi yang sudah tertanam dalam masyarakat. Baik buruknya tradisi ini dapat dilihat sejauh mana bertahannya tradisi tersebut dan tentunya tidak bertentangan dengan ajaran Islam. Tidak dapat dipungkiri, ternyata sampai saat ini, tradisi sumbangan dalam hajatan pernikahan tersebut masih tetap bertahan dan berjalan sebagaimana mestinya. Ini menjadi bukti bahwa tradisi ini sangat baik dan harus dipertahankan, karena tradisi ini juga sama dengan tradisi tolong menolong yang telah menjadi jati diri masyarakat muslim. Dalam tradisi Islam, memang tidak disebutkan aturan yang jelas terkait pemberian sumbangan dalam acara pernikahan, akan tetapi
\end{abstract}


dijelaskan tentang inti dari pelaksanaan hajatan pernikahan yang digelar sebagai wujud rasa syukur atas diadakannya acara sakral dalam kehidupan seseorang.

Kata kunci: Tradisi, Sumbangan, Hajatan Pernikahan, Fiqbul Islam.

\begin{abstract}
In this article we will discuss a little about donations given during a wedding celebration. So it can be illustrated that all levels of society consider it important to apply the tradition of donations in the celebration of marriage. This problem will be examined using a research method with a qualitative approach, which is a research process and understanding based on methodologies that investigate social phenomena and human problems. Regarding the tradition of donations in the celebration of marriage has become a tradition that has been embedded in society. The pros and cons of this tradition can be seen how far the tradition survives and certainly does not conflict with Islamic teachings. It cannot be denied, it turns out that until now, the tradition of donations in the celebration of the marriage still survives and runs as it should. This is proof that this tradition is very good and must be maintained, because this tradition is also the same as the tradition of helping to help that has become the identity of Muslim communities. In the Islamic tradition, there are no clear rules related to giving donations at weddings, but it is explained about the essence of the celebration of weddings held as a form of gratitude for holding a sacred event in one's life.
\end{abstract}

Keywords: Tradition, Donations, Wedding Celebration, Fiqhul Islam

\section{Pendahuluan}

Negara Indonesia yang terdiri dari beberapa pulau ini tergabung dalam satu negara kesatuan yang disebut dengan NKRI (Negara Kesatuan Republik Indonesia). Dari beberapa pulau tersebut mempunyai bermacam ragam adat budaya dan hukum adatnya. Tentunya hal tersebut dimiliki oleh setiap suku-suku di suatu daerahnya tersendiri. Setiap masyarakat atau suku tertentu pasti memiliki aturan dan tatacara tersendiri dalam menjalankan kehidupan sehari-hari. Walaupun demikian, perbedaan tersebut terbingkai dalam negara Pancasila. ${ }^{1}$

1 Hilman Hadikusuma, Hukum Perkawinan Adat dengan Adat Istiadat dan
Untuk dapat menciptakan tata kehidupan yang tertib, diperlukan kesadaran manusia tentang keadaan dirina karena kepentingan antar sesama manusia saling bersamaan dan berbenturan, sehingga diperlukan aturan-aturan dalam masyarakat. Aturan-aturan yang tumbuh dalam kehidupan masyarakat tersebut biasa disebut dengan norma. Norma dapat dibedakan kepada empat macam, yaitu norma agama, norma kesusilaan, norma kesopanan, dan norma hukum. ${ }^{2}$

Upacara Adatnya, cet. Ke-6, Bandung: Citra Aditya Bakti, 2003, hlm. 11.

2 C.S.T Kansil, Pengantar Umum Hukum dan Tata Hukum Indonesia, (Jakarta: Balai Pustaka, 1986), hlm. 84. 
Terlebih lagi, masyarakat yang cenderung bersifat tradisional. Dikarenakan hubungan yang dijalin masih bersifat tradisional, maka tindakan dan segenap aktivitas atau perilaku masyarakat di dalamnya masih bersifat tradisional pula. Weber mengungkapkan, sebagaimana dikutip oleh George Ritzer, bahwa tindakan tradisional adalah tindakan yang didasarkan atas kebiasaankebiasaan dalam mengerjakan sesuatu di masa lalu saja. ${ }^{3}$

Menurut Redfield, ciri-ciri masyarakat tradisional diantaranya adalah masyarakat yang memiliki sistem sosial yang teratur dengen perilaku tradisionalnya. Jumlah penduduknya kecil dengan tempat tinggal yang jauh dari keramaian kota. Masyarakat tradisional juga bersifat homogen dengan rasa persatuan dan persaudaraan yang kuat. Selain itu, masyarakat tradisional juga taat pada ajaran-ajaran agama dan menurut pada pemuka agama. ${ }^{4}$ Sehingga sikap persaudaran diciptakan oleh sebuah norma yang mengatur segala tingkah laku masyarakat desa yang cenderung bersifat tradisional. Selain masyarakat desa, juga ada masyarakat kota yang sama memiliki persaudaraan. Tapi hanya tingkah laku yang bersifat modern yang menjadikan masyarakat kota berbeda dengan masyarakat desa.

Berkaitan dengan aturan-aturan yang tumbuh dalam kehidupan masyarakat, ada persoalan yang menempatkan masyarakat sebagai unsur utamanya, yaitu dalam masalah pernikahan. Pernikahan merupakan suatu wadah penyaluran kebutuhan biologis bagi manusia. Pernikahan ada sebuah sunnah yang mulia yang telah dilakukan oleh para Nabi dan Rasul serta generasi awal dan akhir yang mengikuti petunjuk mereka.

3 George Ritzer, Teori Sosiologi, (Yogyakarta: Pustaka Pelajar, 2012), hlm. 220

4 Darsono Wisadirana, Sosiologi Pedesaan, (Malang: UMM Press, 2004), hlm. 49.
Oleh karena itu, pernikahan yang sarat dengan nilai dan bertujuan untuk mewujudkan kehidupan rumah tangga yang sakinah yang berlandaskan mawaddah dan rahmah, perlu memahami syarat dan rukun tertentu, agar tujuan disyariatkannya pernikahan tercapai. ${ }^{5}$

Sebagai salah satu upaya kemaslahatan sosial, pernikahan merupakan dasar pembentuk dan pembangunan sebuah masyarakat, karena dari sanalah akan muncul generasigenarasi dengan berbagai karakter yang beragam sebagai wujud kedinamisan suatu tatanan sosial. Allah swt telah mensyariatkan pernikahan dengan kebijaksanaan yang tinggi dan tujuan yang mulia. Pernikahan mempunyai tujuan untuk memenuhi naluri hidup manusia, berhubungan antara laki-laki dan perempuan dalam rangka mewujudkan kebahagiaan keluarga sesuai dengan ajaran Allah dan Rasul-Nya. ${ }^{6}$ Adapun sudut pandang sosiologi, pernikahan merupakan upaya penyatuan dua kelompok keluarga besar yang pada awalnya tidak saling mengenal baik dari pihak keluarga laki-laki dan pihak keluarga perempuan serta berdiri sendiri kemudian bersatu dan utuh. $^{7}$

Oleh karena pernikahan itu sarat dengan nilai dengan kebijaksanaan yang tinggi dan tujuan yang mulia, maka diperlukan syarat dan rukun yang harus dipenuhi, diantaranya adalah akad nikah. Oleh sebab itu, akad nikah akan lebih sempurna jika tidak hanya disaksikan oleh dua orang, melainkan juga oleh masyarakat

5 Ahmad Rofiq, Hukum Islam di Indonesia, (Jakarta: PT Raja Grafindo Persada, 1998), hlm. 71

6 Ahmad Azhar Basyir, Hukum Perkawinan Islam, cet. ke-9 (Yogyakarta: UII Press, 1999), hlm. 13.

Khoirudin Nasution, Hukum Perkawinan I, (Yogyakarta: Academia Tazaffa, 2004), hlm. 19. 
luas. ${ }^{8}$ Salah satu jalannya adalah dengan melakukan hajatan pernikahan. Dalam suatu pernikahan diperlukan adanya hajatan pernikahan yang merupakan suatu perayaan yang menyertai adanya akad nikah antara laki-laki dan perempuan. yang juga telah mendapatkan ketentuanketentuan dalam ajaran Islam. ${ }^{9}$ Hajatan pernikahan dalam ajaran agama Islam disebut dengan walimatul 'urs. Walimatul 'urs menurut Islam hukumnya sunnah, sehingga pernikahan diketahui secara umum oleh masyarakat. mengenai tata caranya tidak diatur secara pasti dan rinci terutama berkaitan dengan upacaranya. ${ }^{10}$

Sebagai suatu tradisi yang tumbuh dalam kehidupan masyarakat, maka tentunya pelaksanaan hajatan pernikahan juga harus sejalan dengan aturan-aturan dan norma-norma yang berjalan di masyarakat. Meskipun saat ini untuk melaksanakannya terasa sedikit sulit karena terjadi akulturasi kebudayaan sehingga untuk membedakan mana yang benar dan mana yang salah akan terasa sulit. Terlebih lagi, banyak masyarakat yang mengeluh ketika banyak mendapatkan undangan hajatan pernikahan. Semakin banyak undangan hajatan pernikahan, semakin banyak pula uang yang harus disisihkan untuk menyumbang. Masyarakat sering mengeluh hal ini, namun pada kenyataannya mereka tetap menjalankan kegiatan tersebut meskipun tidak ada hukum tertulis yang mengharuskan masyarakat untuk menyumbang.

Dalam tulisan ini akan sedikit membahas mengenai sumbangan yang diberikan ketika hajatan pernikahan tersebut. Sehingga dapat digambarkan

${ }^{8}$ A. Zuhdi Muhdar, Memahami Hukum Perkawinan, (Bandung: Al-Bayan, 1994), hlm. 64.

${ }^{9}$ Sayyid Sabiq, Fiqih Sunnah, (Kairo: Daar Al-Fatih, 1990), hlm. 333.

10 Sudarsono, Pokok-Pokok Hukum Islam, cet. ke-1, (Jakarta: PT Rineka Cipta, 1992), hlm. 219. bahwa seluruh lapisan masyarakat menganggap penting diterapkan tradisi sumbangan dalam hajatan pernikahan. Tradisi sumbangan dalam penikahan memiliki makna timbal balik yang menimbulkan pemikiran bahwa siapapun yang pernah menyelenggarakan hajatan dan menerima sumbangan harus ganti menyumbang. Hal ini dilakukan agar saat seseorang ingin menyelenggarakan hajatan, maka ia akan memperoleh sumbangan dan uangnya kembali.

Lalu, bagaimana Islam menanggapi persoalan tradisi sumbangan dalam hajatan pernikahan ini. Sebagai suatu tradisi yang tumbuh dalam kehidupan masyarakat, maka tentunya pelaksanaan walimah dalam perkawinan juga harus sejalan dengan aturan-aturan Islam dan normanorma yang berjalan di masyarakat. Meskipun saat ini untuk melaksanakannya, sedikit sulit karena terjadi akulturasi kebudayaan sehingga sedikit banyak menimbulkan kesulitan untuk membedakan mana yang hak dan mana yang bathil. Kenyataannya sampai sekarang, tradisi sumbangan juga masih terdapat dalam struktur masyarakat yang organis, meskipun pada dasarnya tradisi tersebut berasal dari masyarakat yang mekanistik. Kenyataan lainnya, tradisi sumbangan dalam hajatan pernikahan tidak hanya terjadi di masyarakat lokal pedesaan, namun juga ditradisikan oleh masyarakat perkotaan.

Permasalahan ini akan dikaji dengan menggunakan metode penelitian dengan pendekatan kualitatif, yaitu suatu proses penelitian dan pemahaman yang berdasarkan pada metodologi yang menyelidiki suatu fenomena sosial dan masalah manusia. ${ }^{11}$ Tujuan utama penelitian kualitatif adalah untuk memahami fenomena dengan lebih menitikberatkan pada gambaran yang

${ }^{11}$ J.W. Creswell, Qualitatif Inquiry and Research Design, (California: Sage Publications, Inc: 1998), hlm. 15 
lengkap tentang fenomena yang dikaji daripada merincinya menjadi variabelvariabel yang saling terkait. Harapannya ialah diperoleh pemahaman yang mendalam tentang fenomena yang dikaji. ${ }^{12}$ Adapun bentuk analisis data yang digunakan adalah analisis deskriptif. ${ }^{13}$ Pergerakannya tidak hanya sebatas pengumpulan dan penyusunan data, tapi mencakup analisis dan interpretasi tentang data itu. Secara fundamental, dapat dikatakan bahwa sebuah deskripsi adalah representasi objektif terhadap fenomena yang dikaji. ${ }^{14}$

Moleong (2002, 3) menyatakan bahwa penelitian kualitatif merupakan tradisi tertentu dalam ilmu pengetahuan sosial yang secara fundamental bergantung pada pengamatan manusia dalam kawasannya sendiri dan berkenaan dengan orang-orang tersebut dalam bahasanya dan dalam peristilahannya. ${ }^{15}$ Fokus penelitian dalam karya ilmiah ini berdasarkan pada ditemukannya suatu kondisi permasalahan terkait dengan tradisi pemberian sumbangan dalam hajatan pernikahan menurut tradisi Islam. Tujuan dari fokus penelitian ini ialah untuk mengidentifikasi faktor-faktor yang menyebabkan berbagai permasalahan yang muncul untuk kemudian memberikan solusi praktis atas suatu permasalahan. Justifikasi yang dimunculkan dalam penelitian berdasarkan pertimbangan bahwa dalam kasus tersebut

12 Agus Salim, Teori dan Paradigma Penelitian Sosial: Dari Denzim Guba dan Penerapannya, (Yogyakarta: Tiara Wacana, 2001), hlm. 11

13 Jacob Vredenberg, Metode dan

Teknik Penelitian Masyarakat, (Jakarta: Gramedia, 1986), hlm. 34

14 Winarno Surachmad, Dasar dan

Teknk Research: Pengantar Metodologi Ilmiah, (Bandung: Tarsito, 1970), hlm. 133

${ }^{15}$ Lexy J. Moleong Metode Penelitian Kualitatif, (Bandung: Remaja Rosdakarya 2002), hlm. 3 memungkinkan peneliti membongkar atau mengungkapnya. ${ }^{16}$

\section{Tradisi Hajatan Pernikahan dalam Islam}

Dalam ajaran Islam, upacara perkawinan ada dua macam, yaitu upacara yang dilakukan antara calon suami dan wali dari calon istri, yang disebut juga dengan walimatul 'aqdi, dan ada juga upacaraa yang dilakukan setelah terjadinya hubungan suami istri ( $b a^{\prime} d a$ dukhul), atau sebelumnya disebut juga dengan walimatul urs yang kini dikenal dengan hajatan pernikahan.

Walimatul 'urs secara bahasa berasal dari al-walamah (berkumpul), karena banyak manusia yang berkumpul menghadiri suatu jamuan, dan al-urs (pernikahan). Walimatul diserap dalam bahasa Indonesia menjadi walimah atau hajatan pernikahan, dalam literatur arab secara arti kata, berarti jamuan yang khusus untuk pernikahan dan tidak digunakan untuk perhelatan di luar pernikahan. Berdasarkaan pendapat ahli bahasa di atas, untuk selain perhelatan pernikahan tidak digunakan kata walimah meskipun juga menghidangkan makanan. ${ }^{17}$

Dalam fikih Islam, hajatan pernikahan mengandung makna yang umum dan makna yang khusus. Makna yang umum adalah seluruh bentuk perayaan yang melibatkan banyak orang, sedangkan hajatan pernikahan dalam pengertian khusus disebut dengan walimatul 'urs, yang mengandung pengertian peresmian penikahan yang tujuannya untuk memberitahukan kepada khalayak ramai bahwa kedua calon pengantin telah resmi menjadi suami istri, sekaligus rasa syukur kepada Allah atas

16 Tohirin, Metode Penelitian Kualitatif dalam Pendidikan dan Bimbingan Konseling, (Jakarta: Rajawali Pers, 2013), hlm. 22

${ }^{17}$ Amir Syarifudin, Hukum Perkawinan Islam di Indonesia, (Jakarta: Prenada Media, 2006), hlm. 155. 
berlangsungnya pernikahan tersebut. Hajatan pernikahan dapat juga berarti melaksanakan suatu jamuan makan sebagai pencetusan tanda gembira atau lainnya, tetapi biasanya jika menyebut hajatan pernikahan maksudnya adalah walimatul 'urs yang artinya perayaan pernikahan.

Sebagai suatu tradisi yang tumbuh dan berkembang di masyarakat, tentunya pelaksanaan hajatan pernikahan juga harus sejalan dengan aturan-aturan Islam serta norma-norma yang ada pada masyarakat itu sendiri, meskipun saat ini untuk melaksanakannya terasa sedikit sulit karena terjadi akulturasi kebudayaan sehingga untuk membedakan mana yang benar dan mana yang salah akan terasa sulit. Jika suatu warga masyarakat muslim memiliki komitmen yang sungguhsungguh dalam melaksanakan ajaran Islam, termasuk ajaran tentang pelaksanaan hajatan pernikahan. Sebenarnya Islam tidak menghendaki kesulitan bagi umat dalam melaksanakan ajaran-ajarannya. Sesuai dengan firman Allah swt:

\section{يريد الله بكم اليسر ولا يريد بكم العسر}

Artinya: "Allah menghendaki kemudahan bagimu, dan tidak menghendaki kesukaran bagimu”."

Salah satu bukti bahwa Islam tidak memberikan kesulitan dalam pelaksanaan ajarannya seperti dalam hajatan pernikahan, Islam hanya mengutamakan terlaksananya, walaupun hanya dikemas dengan sederhana. Dari pada memeriahkannya yang menjurus ke arah hura-hura dan menghambur-hamburkan biaya.

Hajatan dalam pernikahan adalah selain sebagai pengumuman bahwa pasangan mempelai telah sah dan resmi

\footnotetext{
${ }^{18}$ Q.S al-Baqarah (2): 185
}

sebagai suami istri, juga sebagai tanda rasa syukur kepada sang Pencipta, walaupun hanya melaksanakannya dengan menyembelih seekor kambing. Pelaksanaan hajatan pernikahan, meskipun bukan merupakan syarat sahnya pernikahan, namun merupakan hal yang amat penting, dalam kedudukannya sebagai sarana untuk mensiarkan adanya suatu pernikahan. Sedangkan mensiarkan pernikahan, sebagaimana yang dikemukakan oleh Sayyid Sabiq merupakan tindakan yang dipandang baik menurut syara', agar terhindar dari nikah sirri yang terlarang dari untuk menampakkan rasa bahagia atas apa yang dihalalkan oleh Allah dari segala hal yang baik. $^{19}$

Urgensi pelaksanaan hajatan dalam pernikahan terbukti pula karena Rasulullah sendiri tidak pernah meninggalkannya, baik ketika Rasulullah berada di kampung halaman maupun ketika dalam perjalanan. ${ }^{20}$ Praktek Rasulullah tersebut menjadi petunjuk bagi seluruh umat Islam, bahwa hajatan pernikahan hendaknya sedapat mungkin dilaksanakan, dalam keadaan bagaimanapun dengan memperhatikan kemampuan masingmasing. Kemampuan untuk melaksanakan hajatan pernikahan pada suatu masyarakat, tentunya berbeda-beda. Ada yang hanya mampu melaksanakannya dalam acara yang amat sederhana, dan ada pula yang dapat mengadakan acara yang lebih meriah dalam pelaksanaannya.

Mengingat bahwa hajatan dalam pernikahan merupakan tradisi yang hidup dalam masyarakat, maka tradisi itu harus dipelihara, karena dipandang dari tujuannya, hajatan pernikahan itu merupakan tradisi yang baik. Sedangkan memelihara tradisi yang baik itu

${ }^{19}$ Sayyid Sabiq, Fiqih Sunnah, (Kairo: Daar Al-Fatih, 1990), hlm. 333

${ }^{20}$ Imam Taqiyuddin, Kifayat al-Akhyar Fi Halli Gayat al-Ikhtisar, (Bandung: Syirkah alMa'arif, t.t), hlm. 68 
merupakan suatu keharusan, bahkan mengenai status tradisi dalam ajaran Islam, ulama menyatakan bahwa tradisi adalah syariat yang dikukuhkan sebagai hukum. Pernyataan ini terangkum dalam kaidah fiqhiyyah berikut:

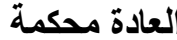 \\ Artinya: "Kebiasaan itu menjadi bukum"."}

Jadi dengan kaidah tersebut dapat dipahami bahwa ketika tradisi hajatan dalam pernikahan diperbolehkan, maka perbuatan itu sah untuk direalisasikan dengan catatan selama tidak menghadirkan penderitaan bagi diri sendiri maupun orang lain. Kaidah tersebut juga dapat dipahami sebagai adanya suatu gagasan tentang sikap menghormati dan menghargai praktik lokal sebagai perwujudan dari rasa keadilan masyarakat setempat.

Dalam pembahasan tentang hajatan pernikahan pada suatu masyarakat, perlu diketahui secara jelas apakah tradisi masyarakat tersebut ada penjelasannya dalam ajaran Islam atau sebaliknya. Ini merupakan hal penting, agar umat Islam dapat tetap konsisten pada ajaran agamanya, karena dalam kehidupan sekarang yang terus berkembang, nilainilai dari ajaran yang luhur dan mulia terkadang begitu mudah diabaikan, hanya dengan alasan mengikuti perkembangan zaman. Padahal seperti yang telah diketahui, ajaran Islam mempunyai kemampuan bergerak dan berkembang, mempunyai daya hidup, dapat membentuk diri sesuai dengan perkembangan dan kemajuan. ${ }^{22}$

21 Abdurrahman as-Suyuti, al-Asybah wa an-Nazair fi Qawaid wa Furu Fiqh asySyafi'i, jilid 2, (Bairut: Dar al-Kutub al-Ilmiyah), hlm. 89. Lihat juga Samsul Ma'arif, Kaidahkaidah Fiqih, cet. ke-1, (Bandung: Pustaka Ramadhan, 2005), hlm. 31

${ }^{22}$ Hasbi as-Shiddiqy, Filsafat Hukum Islam, (Jakarta: Bulan Bintang, 1993), hlm. 108.

\section{Pemberian Sumbangan sebagai Pertukaran Sosial}

Segala bentuk pemberian yang terjadi di masyarakat selalu diikuti oleh suatu pemberian kembali (imbalan). Kebiasaan saling tukar-menukar pemberian itu adalah suatu proses sosial yang dinamik yang melibatkan keseluruhan anggota masyarakat sebagai sistem yang menyeluruh. Proses dinamik tersebut terwujud melalui hakikat saling memberi yang mengharuskan sipenerima untuk mengimbangi bahkan melebihi pengembalian pemberian. Hal inilah yang mencerminkan adanya persaingan kedudukan dan kehormatan dari pihakpihak yang bersangkutan, sehingga saling tukar-menukar tersebut tidak ada habishabisnya dari waktu ke waktu.

Saling tukar menukar pemberian, menurut Marcel Mauss mempunyai ciriciri sebagai berikut: a) pengembalian benda yang diterima tidak dilakukan pada saat pemberian hadiah itu diterima, tetapi pada saat yang berbeda sesuai dengan adat kebiasaan yang berlaku, b) pengembalian pemberian hadiah yang diterima tidak berupa barang yang sama dengan yang diterima, tetapi dengan benda berbeda yang mempunyai nilai yang sedikit lebih tinggi atau setidaknya sama dengan hadiah yang telah diterima, c) benda-benda pemberian yang terima tidak dilihat sebagai benda dalam nilai harfiahnya, tetapi sebagai prestasi.

Prinsip timbal balik atau pertukaran dalam masyarakat sebenarnya juga merupakan bagian dari solidaritas, namun dalam konteks yang lebih luas solidaritas ini diperkuat oleh tindakan pemberian dan saling tukar menukar. Hal ini sesuai dengan pernyataan berikut ini:

"Social ties are created, sustained are strenghened by means of gift. Act of gift exchange are at the basic of human solidarity". ${ }^{23}$

23 Maksud dari pernyataan tersebut adalah hubungan sosial diciptakan, ditopang dan 
Mauss dalam analisa gift-givingnya menjelaskan bahwa dalam konsep pemberian, terkandung pengertian bahwa orang memiliki kewajiban untuk mengembalikan pemberian yang telah diterimanya tersebut. Mauss memberikan gambaran atas pemberian ke dalam tiga bentuk kewajiban, yaitu kewajiban untuk memberi, kewajiban untuk menerima dan kewajiban untuk mengembalikan. Setiap pemberian memili beban kewajiban tertentu yang menjadi bagian dari aktivitas huubungan timbal balik dalam masyarakat. Kewajiban untuk memberi berhubungan dengan pemberian penghargaan atau pelayanan atas apa yang diterimanya. ${ }^{24}$

Pertukaran sosial tidak hanya melibatkan kepentingan individu dengan individu lain, tapi ada aktivitas transaksional yang melibatkan individu dalam rangka mempertahankan peranan dalam kelompok sosial masyarakat. Hubungannya dengan prinsip sumbangan, seseorang memberikan sumbangan bukan hanya sebagai wujud pertukaran yang melibatkan kepentingan individu, tetapi lebih dari itu, ada kepentingan transaksional yang mendasari keinginan untuk diakui dalam kehidupan kelompok sosial masyarakat.

Berkaitan dengan hal tersebut, kebiasaan masyarakat dalam melaksanakan hajatan pernikahan dilakukan dengan disertai tradisi sumbangan dalam hajatan ketika waktu walimah (hiburan) terjadi. Wujud dari pemberian sumbangan dalam hajatan, dalam hal ini diberikan kepada kedua orang tua mempelai dan kedua pengantin. Sumbangan tersebut

diperkuat oleh pemberian. Aktivitas tukar menukar pemberian adalah dasar dari solidaritas manusia. Lihat Aafke E Komter, Social Solidarity and The Gift, (Cambridge University Press, 2005), hlm. 116-117.

24 Marcel Mauss, Pemberian, terj. Parsudi Suparlan, (Jakarta: Yayasan Obor Indonesia, 1992), hlm. 57. diwujudkan berupa uang, serta bingkisan kado.

Konsep pemberian seperti di atas dapat dikatakan sesuai pada fenomena tradisi sumbangan dalam hajatan pernikahan. Sumbangan yang pada dasarnya adalah perwujudan gotong royong atau saling bantu membantu untuk menolong orang lain dan dilakukan secara sukarela. Namun kenyataannya, hal tersbeut mengandung sebuah praktik pertukaran sosial di dalamnya. Prestasi yang dipertukarkan berupa sumbangan yang diberikan untuk seseorang yang sedang menyelenggarakan hajatan. Adanya tradisi yang tujuannya untuk mengembalikan kembali apa yang telah diberikan membuat tradisi sumbangan tidak lagi bersifat sukarela. Hal inilah yang menyebabkan aktifitas ini terjadi secara terus menerus dan cenderung membelenggu masyarakat. Selain itu, terdapat sanksi moral jika seseorang tidak membalas sumbangan yang pernah diberikan seseorang kepadanya, tentunya hal itu membuat seseorang tersebut merasa dipaksa bahkan dalam keadaan ekonomi yang terbatas.

\section{Tradisi Pemberian Sumbangan Berdasarkan Fiqhul Islam}

Sebagaimana diketahui bersama, agama Islam adalah agama yang komperhensif, mencakup segala aspek kehidupan sosial manusia. Sebagaimana tercantum dalam firman-Nya:

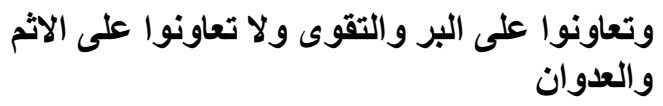

Artinya: "Dan saling tolong menolonglab kamu dalam hal kebaikan dan ketakwaan, dan janganlah kamu saling tolong menolong dalam bal perbuatan dosa dan permusuban". ${ }^{25}$ 
Termasuk juga dalam hal yang tidak lepas dari perhatian ajaran agama Islam, adalah aturan-aturan pernikahan, yang dalam hukum Islam dinyatakan sebagai akad yang kuat untuk mentaati perintah Allah dan melaksanakannya termasuk ibadah, dengan tujuan pencapaian rumah tangga yang sakinah, mawaddah, warahmah. ${ }^{26}$

Ketentuan hukum pernikahan dalam ajaran agama Islam telah dibahas secara rinci dan jelas mulai dari memilih pasangan, sampai dengan terlaksananya pernikahan itu sendiri hingga sampai kepada akibat pernikahan tersebut. Tentunya tradisi hajatan pernikahan jug atelah mendapatkan ketentuan-ketentuan dalam hukum Islam. ${ }^{27}$

Pada pelaksanaan pernikahan, diperlukan syarat dan rukun yang harus dipenuhi. Diantaranya, adanya rasa suka sama suka dari kedua calon mempelai, adanya ijab dan kabul, adanya mahar atau mas kawin, adanya wali, dan adanya saksisaksi. Akad nikah adalah suatu batas hubungan seorang laki-laki dan perempuan yang semula haram menjadi halal dan juga merupakan ikatan baru dalam masyarakat. Oleh sebab itu, akad nikah akan lebih sempurna jika tidak hanya disaksikan oleh dua orang, melainkan juga oleh masyarakat luas. ${ }^{28}$

Dalam pembahasan tentang tradisi pemberian sumbangan dalam hajatan pernikahan pada suatu masyarakat, perlu diketahui secara jelas apakah tradisi tersebut ada ketentuannya di dalam ajaran Islam. Sehubungan dengan tradisi pemberian sumbangan dalam hajatan pernikahan pada masyarakat sekarang (baik masyarakat desa maupun masyarakat

26 Pasal 2 dan 3 Kompilasi Hukum

Islam

${ }^{27}$ Sayyid Sabiq, Fiqih Sunnah, (Kairo: Daar Al-Fatih, 1990), hlm. 333

${ }^{28}$ A. Zuhdi Muhdar, Memahami Hukum Perkawinan, (Bandung: Al-Bayan, 1994), hlm. 64 kota), tidak mustahil dalam tradisi dan pelaksanaannya mengandung berbagai kemungkinan, baik yang sesuai dengan ketuntuan ajaran Islam, maupun yang tidak sesuai dengan ajaran Islam. Maka perlu dicermati untuk dikaji bagian mana yang bertentangan dengan ajaran Islam dan yang tidak bertentangan sehingga adanya kepastian hukum.

Mengenai tradisi sumbangan dalam hajatan pernikahan ini sudah menjadi tradisi yang sudah tertanam dalam masyarakat. Baik buruknya tradisi ini dapat dilihat sejauh mana bertahannya tradisi tersebut dan tentunya tidak bertentangan dengan ajaran Islam. Tidak dapat dipungkiri, ternyata sampai saat ini, tradisi sumbangan dalam hajatan pernikahan tersebut masih tetap bertahan dan berjalan sebagaimana mestinya. Ini menjadi bukti bahwa tradisi ini sangat baik dan harus dipertahankan, karena tradisi ini juga sama dengan tradisi tolong menolong yang telah menjadi jati diri masyarakat muslim.

Sebenarnya tantangan yang harus dihadapi saat ini adalah bagaimana kita menghadapi beraneka ragam budaya, tradisi sosial dan keyakinan agama yang telah demikian mengakar ditengah masyarakat kita. ${ }^{29}$ Oleh karena itu, segala aspek budaya Islam dapat dikenal dalam kancah sejarah dan sudah menjadi paradigma baru dalam menilai sebuah fakta. Mengenai tradisi (adat), dalam Fiqhul Islam biasanya disebut dengan istilah urf. Kata 'urf berasal dari 'arafa, dan sering diartikan sebagai ma'ruf dengan arti sesuatu yang dikenal. Kata 'urf juga terdapat dalam al-Qur'an dengan arti ma'ruf yang artinya kebajikan (berbuat baik), seperti dalam ayat:

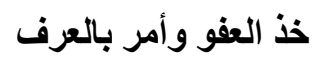

29 Mabni Darsi, Menjadi Pasangan Paling Bahagia, (Jakarta: Gadika Pustaka, 2007), hlm. 21 . 
Artinya: "Jadilah pemaaf dan surublah orang mengerjakan yang makruf, serta jangan pedulikan orang-orang yang bodob". ${ }^{30}$

Urf merupakan sesuatu yang telah dikenal oleh orang banyak dan telah menjadi tradisi bagi mereka baik berupa perkataan, perbuatan, atau keadaan meninggalkan. 'Urf adalah bentuk-bentuk muamalat atau hubungan kepentingan yang telah menjadi adat kebiasaan dan telah berlangsung konstan di tengahtengah masyarakat. 'Urf sendiri dapat berarti apa-apa yang telah dibiasakan oleh masyarakat dan dijalankan terus-menerus baik perkataan maupun perbuatan. 'Urf disebut juga sebagai alat kebiasaan.

Imam Malik mendasarkan sebagian hukumnya kepada amal perbuatan penduduk Madinah. Imam Abu Hanifah bersama murid-muridnya berbeda pendapat dalam beberapa hukum dengan dasar atas perbedaan Urf mereka. Imam Syafi'i ketika berada di Mesir mengubah sebagian hukum yang telah menjadi pendapatnya ketika beliau berada di Baghdad, hal ini dikarenakan perbedaan Urf antara Mesir dan Baghdad (qaul qodim dan qaul jadid)..$^{31}$

Para ulama ushul figh membagi 'urf menjadi tiga macam. Dari segi objek, 'urf terbagi menjadi dua macam, yaitu:

1. al-Urf al-Lafæzbi adalah kebiasaan masyarakat dalam menggunakan lafal atau ungkapan tertentu dalam mengungkapkan sesuatu, sehingga makna ungkapan tertentu dalam mengungkapkan sesuatu, sehingga makna ungkapan itulah yang dipahami dan terlintas dalam pikiran masyarakat.

2. al-Urf al-'Amali adalah kebiasaan masyarakat yang berkaitan dengan perbuatan biasa atau mu'amalah keperdataan. Adapun yang dimaksud

\footnotetext{
30 al-A'raf (7): 199.

31 Abdul Wahhab Khallaf, Kaidahkaidah Hukum Islam, (Jakarta: PT Raja Grafindo, 1996), hlm. 135.
}

"perbuatan biasa" adalah perbuatan masyarakat dalam masalah kehidpuan mereka terkait dengan kepentingan orang lain.

Dari segi cakupannya, urf terbagi menjadi dua, yaitu:

1. Urf al-'Am (kebiasaan bersifat umum) adalah kebiasaan tertentu yang berlaku secara luas di seluruh masyarakat dan di seluruh daerah.

2. Urf al-Khas (kebiasaan yang bersifat khusus) adalah kebiasaaan yang berlaku di daerah dan masyarakat tertentu dan tidak terhitung jumlahnya serta senantiasa berkembang sesuai dengan perubahan situasi dan kondisi masyarakat. ${ }^{32}$

Dari segi fungsi, 'urf dapat dibedakan menjadi dua macam, yaitu 'Urf Sabih dan Urf Fasid. Urf Sabih ialah yang sudah dikenal oleh manusia dan tidak bertentangan dengan dalil syara', juga tidak menghalalkan yang haram dan tidak membatalkan yang wajib. Sedangkan Urf Fasid ialah yang telah dikenal oleh manusia, tetapi bertentangan dengan dalil syara' atau menghalalkan yang haram atau membatalkan yang wajib. ${ }^{33}$ Berkaitan dengan tradisi sumbangan dalam hajatan pernikahan yang dikemukakan pengertiannya di atas, menurut penulis harus dipelihara baik pelaksanaannya maupun teori penetapan hukum kebiasaannya.

Para ulama mengamalkan 'urf itu dalam memahami dan mengistimbatkan hukum, menetapkan beberapa persyaratan untuk menerima 'urf tersebut, yaitu:

1. Adat atau 'urf bernilai maslahat dan dapat diterim oleh akal sehat. Syarat in telah merupakan kelaziman bagi adat atau 'urf yang sahih, sebagai

\footnotetext{
${ }^{32}$ Nasrun Haroen, Ushul Fiqh I, cet. ke3, (Jakarta: Logos Wacana, 2011), hlm. 139.

33 Abdul Wahab Khallaf, Ilmu Usul Fiqh, (Kairo: Maktabah ad-Dakwah al-Islamiyah Syabab al-Azhar, 1990), hlm. 89.
} 
persyaratan untuk diterima secara umum.

2. Adat atau 'urf itu berlaku untuk umum dan merata di kalangan orangorang yang berbeda dalam lingkungan adat tersebut atau di kalangan sebagian warganya.

3. Urf yang dijadikan sandaran dalam penetapan hukum itu telah ada (berlaku) pada saat itu, bukan urf yang muncul kemudia. Hal ini berarti "urf harus telah ada sebelum penetapan hukum. Kalau 'urf itu datang kemudian, maka tidak diperhitungkan. ${ }^{34}$

Adat kebiasaan yang sudah mengakar dalam kehidupan masyarakat selama kebiasaan tersebut tidak mendatangkan kerusakan atau menyalahi norma umum dan syariat agama maka dapat diterima dan berjalan terus sebagai salah satu dasar dalam pengembilan keputusan hukum.

Untuk dapat tetap terpelihara suatu tradisi, harus memenuhi syaratsyarat tertentu. Adapun syarat-syarat yang harus ada dalam suatu tradisi sebagai sumber hukum adalah sebagai berikut:

a. Tradisi tidak berlawanan dengan nash yang tegas.

b. Tradisi atau adat telah menjadi perilaku yang terus menerus berlaku dan berkembang dalam masyarakat

c. Tradisi itu merupakan al-urf (kebiasaan) yang umum, karena hukum yang umum tidak dapat ditetapkan dengan al-urf yang khusus.

Dengan menelusuri aturan-aturan hukum Islam tentang pernikahan, maka akan dapat diketahui shahih atau fasidnya tradisi tersebut. Kaitannya dengan tradisi sumbangan dalam hajatan pernikahan, sesuai atau tidaknya pelaksanaan tradisi tersebut dengan prinsip-prinsip pelaksanaan pernikahan dalam ajaran Islam.
Sebagaimana telah diketahui, umat Islam dalam berbagai aspek kehidupannya harus senantiasa berpegang teguh pada ajaran yang dibawa oleh Rasulullah saw. Jadi dalam tradisi sumbangan hajatan pernikahan yang dilakukan masyarakat sekarang, menurut penulis tentu telah menjiwai tradisi yang pernah dipraktekkan pada masa Rasulullah. Sebagai bukti, masyarakat senantiasa mengikuti apa yang diperintahkan oleh Rasulullah dan menghindari larangan. Karena umat Islam berkewajiban untuk melaksanakan segala apa yang diperintahkan oleh Rasulullah dan menghindari segala apa yang dilarang. Seperti yang ditegaskan dalam firman Allah:

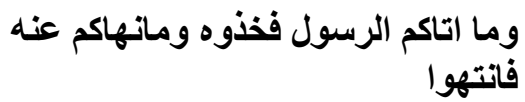

Artinya: "Dan suatu yang diberikan Rasulullah kepadamu maka terimalah, dan suatu yang dilarangnya bagimu maka tinggalkanlab"."35

Dalam tradisi Islam, memang tidak disebutkan aturan yang jelas terkait pemberian sumbangan dalam acara pernikahan, akan tetapi dijelaskan tentang inti dari pelaksanaan hajatan pernikahan yang digelar sebagai wujud rasa syukur atas diadakannya acara sakral dalam kehidupan seseorang.

Untuk memperoleh ketetapan hukum, tentang tradisi sumbangan dalam hajatan pernikahan, selain menggunakan Urf sebagai ketetapan hukum, dapat pula digunakan konsep maslahab untuk menyelesaikan masalah ini. Karena tradisi sumbangan dalam hajatan pernikahan yang dipraktekkan oleh masyarakat tersebut tentunyamengandung manfaat, walaupun belum diketahui sebesar apa manfaat yang terkandung di dalam tradisi tersebut. 
Dalam mempergunakan maslahah sebagai landasan hukum suatu masalah, para ulama yang menjadikannya sebagai sumber hukum menetapkan beberapa syarat untuk membedakan antara maslahah yang benar dengan maslabah yang digerakkan oleh hawa nafsu. Ulama mensyaratkan supaya maslahab itu berupa maslahah yang sebenarnya, bukan maslahah yang bersifat dugaan. Maksudnya agar dapat direalisasikan bahwa pembentukan hukum suatu kejadian dapat mendatangkan keuntungan kepada kebanyakan umat manusia, atau dapat menolak mudarat, dan bukan mendatangkan keuntungan kepada seseorang atau beberapa orang saja diantara mereka, berupa maslabah yang tidak bertentangan dengan hukum atau prinsip yang telah ditetapkan oleh nash atau ijma. ${ }^{36}$

Maka dalam upaya memperoleh ketetapan hukum Islam tentang tradisi sumbangan dalam hajatan pernikahan, berdasarkan kemaslahatan yang terkandung dalam tradisi tersebut, maka lebih besar manfaat daripada mudarat yang dirasakan dalam tradisi tersebut. Sehingga dapat dipastikan bahwa tradisi sumbangan dalam hajatan pernikahan tidak bertentangan dengan ajaran Islam. Sebagaimana dikemukakan oleh asShiddiqy, kemaslahatan itu dilakukan dengan dua usaha besar, yaitu menolak kemudaratan yang menimpa manusia umumnya dan menimpa umat Islam khususnya, dan mendatangkan kemanfaatan yang menghasilkan kebaikan bagi seluruh manusia pada umumnya dan bagi umat Islam pada khususnya. ${ }^{37}$

Dalam mengatur seluruh aspek kehidupan manusia, hukum Islam merupakan suatu hukum yang bersifat universal yaitu hukum Islam dapat

\footnotetext{
${ }^{36}$ Abdul Wahhab Khallaf, Ilmu Ushul Fikih, hlm. 86-87.

37 Hasbi as-Shiddiqy, Filsafat Hukum Islam, hlm. 338.
}

memberikan solusi dan petunjuk yang mudah dalam menjelaskan mana yang hak dan mana yang bathil sesuai dengan alQur'an dan as-Sunnah, akan tetapi meskipun petunjuk sudah lengkap dan sesuai dengan kaidah zaman dan waktu, ajaran Islam masih memberikan porsi nalar bagi manusia. Oleh karena itu, manusia masih bisa menetapkan hukum dengan berpedoman pada al-Qur'an dan as-Sunnah terhadap permasalahanpermasalahan yang tidak ada nash dan hukumnya secara jelas.

Aturan-aturan pelaksanaan mengenai hajatan pernikahan dalam hukum Islam begitu fleksibel. Pada dasarnya ajaran Islam memberikn kewenangan kepada masyarakat muslim untuk melaksanakannya sesuai dengan keinginan mereka. Apapun boleh dilakukan asalkan tetap menjaga supaya tindakan tersebut tidak menyimpang dari norma-norma agama. Pentingnya pelaksanaan walimah telah terbukti karena Rasulullah tidak pernah meninggalkannya, baik ketika beliau berada di kampung halaman maupun pada saat di perjalanan. ${ }^{38}$

Oleh karena itu, upaya dalam memperoleh ketetapan hukum Islam tentang tradisi sumbangan pada hajatan pernikahan di masyarakat, perlu diketahui bahwa besar manfaat daripada mudarat yang dapat dirasakan dari tradisi tersebut, sehingga dapat dipastikan langkah yang tepat untuk melestarikan tradisi sumbangan pada hajatan pernikahan dalam masyarakat tersebut karena tidak bertentangan dengan ajaran Islam.

\section{Kesimpulan}

Uraian dari penjelasan yang telah disebutkan di atas, maka dapat diambil kesimpulan bahwa mengenai sumbangan yang diberikan ketika hajatan pernikahan menurut penulis sangat penting diterapkan

${ }^{38}$ Imam Taqiyuddin, Kifarah al-Akhyar fi Akhyar fi Halli Gayat al-Ikhtisar, (Bandung: Syirkah al-Ma'arif), hlm. 35. 
tradisi tersebut. Di dalam fikih Islam, hajatan pernikahan mengandung yang sarat akan nilai sakral, tujuannya untuk memberitahukan kepada khalayak ramai bahwa kedua calon pengantin telah resmi menjadi suami istri, sekaligus rasa syukur kepada Allah atas berlangsungnya pernikahan tersebut. Sebagai suatu tradisi yang tumbuh dan berkembang di masyarakat, tentunya pelaksanaan hajatan pernikahan juga harus sejalan dengan aturan-aturan Islam serta norma-norma yang ada pada masyarakat itu sendiri, meskipun saat ini untuk melaksanakannya terasa sedikit sulit karena terjadi akulturasi kebudayaan sehingga untuk membedakan mana yang benar dan mana yang salah akan terasa sulit. Jika suatu warga masyarakat muslim memiliki komitmen yang sungguh-sungguh dalam melaksanakan ajaran Islam, termasuk ajaran tentang pelaksanaan hajatan pernikahan.

Mengenai tradisi sumbangan dalam hajatan pernikahan ini sudah menjadi tradisi yang sudah tertanam dalam masyarakat. Baik buruknya tradisi ini dapat dilihat sejauh mana bertahannya tradisi tersebut dan tentunya tidak bertentangan dengan ajaran Islam. Tidak dapat dipungkiri, ternyata sampai saat ini, tradisi sumbangan dalam hajatan pernikahan tersebut masih tetap bertahan dan berjalan sebagaimana mestinya. Ini menjadi bukti bahwa tradisi ini sangat baik dan harus dipertahankan, karena tradisi ini juga sama dengan tradisi tolong menolong yang telah menjadi jati diri masyarakat muslim. Dalam tradisi Islam, memang tidak disebutkan aturan yang jelas terkait pemberian sumbangan dalam acara pernikahan, akan tetapi dijelaskan tentang inti dari pelaksanaan hajatan pernikahan yang digelar sebagai wujud rasa syukur atas diadakannya acara sakral dalam kehidupan seseorang.

Maka dalam upaya memperoleh ketetapan hukum Islam tentang tradisi sumbangan dalam hajatan pernikahan, berdasarkan kemaslahatan yang terkandung dalam tradisi tersebut, maka lebih besar manfaat daripada mudarat yang dirasakan dalam tradisi tersebut. Sehingga dapat dipastikan bahwa tradisi sumbangan dalam hajatan pernikahan tidak bertentangan dengan ajaran Islam. Sebagaimana dikemukakan oleh asShiddiqy, kemaslahatan itu dilakukan dengan dua usaha besar, yaitu menolak kemudaratan yang menimpa manusia umumnya dan menimpa umat Islam khususnya, dan mendatangkan kemanfaatan yang menghasilkan kebaikan bagi seluruh manusia pada umumnya dan bagi umat Islam pada khususnya. []

\section{DAFTAR PUSTAKA}

Al-Munawar, Said Agil. Konsep Maslabah sebagai Salab Satu Sumber Perundangan Islam, Jurnal Islamiyyat. Vol 18-19, TH. 1998.

Basyir, Ahmad Azhar, Hukum Perkawinan Islam, cet. ke-9 Yogyakarta: UII Press, 1999

Creswell, J.W., Qualitatif Inquiry and Research Design, California: Sage Publications, Inc: 1998

Darsi, Mabni, Menjadi Pasangan Paling Bahagia, Jakarta: Gadika Pustaka, 2007

Hadikusuma, Hilman, Hukum Perkawinan Adat dengan Adat Istiadat dan Upacara Adatnya, cet. Ke-6, Bandung: Citra Aditya Bakti, 2003

Haroen, Nasrun, Ushul Fiqh I, cet. ke-3, Jakarta: Logos Wacana, 2011

Kansil, C.S.T, Pengantar Umum Hukum dan Tata Hukum Indonesia, Jakarta: Balai Pustaka, 1986

Khallaf, Abdul Wahab, Imu Usul Figh, Kairo: Maktabah ad-Dakwah alIslamiyah Syabab al-Azhar, 1990

Kaidah-kaidah Hukum Islam, Jakarta: PT Raja Grafindo, 1996 
Komter, Aafke E., Social Solidarity and The Gift, Cambridge University Press, 2005

Ma'arif, Samsul, Kaidah-kaidah Fiqih, cet. ke-1, Bandung: Pustaka Ramadhan, 2005

Mauss, Marcel, Pemberian, terj. Parsudi Suparlan, Jakarta: Yayasan Obor Indonesia, 1992

Moleong, Lexy J. Metode Penelitian Kualitatif, Bandung: Remaja Rosdakarya 2002

Muhdar, A. Zuhdi, Memahami Hukum Perkawinan, Bandung: Al-Bayan, 1994

Nasution, Khoirudin, Hukum Perkawinan I, Yogyakarta: Academia Tazaffa, 2004.

Ritzer, George, Teori Sosiologi, Yogyakarta: Pustaka Pelajar, 2012

Rofiq, Ahmad, Hukum Islam di Indonesia, Jakarta: PT Raja Grafindo Persada, 1998

Sabiq, Sayyid, Fiqih Sunnah, (Kairo: Daar Al-Fatih, 1990.

Salim, Agus, Teori dan Paradigma Penelitian Sosial: Dari Denzim Guba dan Penerapannya, Yogyakarta: Tiara Wacana, 2001

Shiddiqy, Hasbi as-, Filsafat Hukum Islam, Jakarta: Bulan Bintang, 1993

Sudarsono, Pokok-Pokok Hukum Islam, cet. ke-1, Jakarta: PT Rineka Cipta, 1992

Surachmad, Winarno, Dasar dan Teknk Research: Pengantar Metodologi Ilmiah, Bandung: Tarsito, 1970

Suyuti, Abdurrahman as-, al-Asybah wa anNazair fi Qawaid wa Furu Figh asySyafi'i, jilid 2, Bairut: Dar al-Kutub al-Ilmiyah, t.t

Syarifudin, Amir, Hukum Perkawinan Islam di Indonesia, Jakarta: Prenada Media, 2006

Taqiyuddin, Imam, Kifayat al-Akhyar Fi Halli Gayat al-Ikbtisar, Bandung: Syirkah al-Ma'arif, t.t

Tohirin, Metode Penelitian Kualitatif dalam Pendidikan dan Bimbingan Konseling, Jakarta: Rajawali Pers, 2013
Vredenberg, Jacob, Metode dan Teknik Penelitian Masyarakat, Jakarta: Gramedia, 1986

Wisadirana, Darsono, Sosiologi Pedesaan, Malang: UMM Press, 2004. 